\title{
AMERICANS' CULTURAL ATTITUDES TO GROUP WORK: INSIGHTS FROM THE PROVERBS
}

\author{
Mohammad Tamimy ${ }^{1}$, Rahman Sahragard ${ }^{2}$ \\ ${ }^{1,2}$ Department of Foreign Languages and Linguistics, \\ Faculty of Letters and Humanities, Shiraz University, Iran
}

\begin{abstract}
The role of culture, especially the American culture, in group work is relatively understudied because it is often presumed to be no different from the colonialist West, or is alternatively stereotyped as individualistic and competitive. Thus, this paper studies English-language proverbs used in America, as culturally rich symbols, at three levels of discourse, conceptual metaphor, and content to discern what attitude American culture, as represented in the proverbs, has to group work, and what world views and psychosocial factors can inform such attitudes. The findings suggest that American culture is marginally cooperation friendly, with a considerable penchant for individualism and competition. This ambivalence was not simply a proverbial phenomenon, rather a cultural reality because it was observed to be the result of the interplay between heterogeneous conceptual metaphors, representing different world views. Psychosocially, many factors were observed to have molded the American culture's attitude to group work, noticeably, egoism, distrust, altruism, and socially shared cognition.
\end{abstract}

Key words: culture, group work, proverbs, cooperative learning, American culture

About the author: Mohammad Tamimy is a doctorate candidate of Teaching English to the Speakers of Other Languages (TESOL) at the Department of Foreign Languages and Linguistics, Shiraz University, Shiraz, Iran. He is interested in the studies focusing on culture using innovative methodologies. He has published in a few national and international journals including the journal of Intercultural Communication Research. He has also served as a peer-reviewer to a few international journals.

e-mail: mohammad.tamimy@gmail.com ORCID iD: https://orcid.org/0000-0001-6024-6940 m.tamimy@shirazu.ac.ir

About the author: Rahman Sahragard is a full professor in Applied Linguistics at the Department of Foreign Languages and Linguistics, Shiraz University, Iran and currently serves as the dean of the Faculty of Letters and Humanities. He obtained his PhD from Leicester University, UK, in 2001. He sits on editorial board of a few Iranian and International journals and has extensively published on different topics including discourse analysis, material development, and language teaching.

e-mail: rsahragard@rose.shirazu.ac.ir

ORCID iD: https://orcid.org/0000-0002-6615-9466

Copyright $\odot 2021$ Mohammad Tamimy, Rahman Sahragard

Article history: Received: 13 October 2021; Reviewed: 31 October 2021; Revised: 4 November 2021; Accepted: 4 November 2021; Published: November 2021

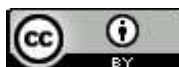

This open access article is published and distributed under a Creative Commons Attribution 4.0 International License.

Citation (APA): Tamimy, M., \& Sahragard, R. (2021). Americans' cultural attitudes to group work: Insights from the proverbs. Studies in Linguistics, Culture, and FLT, 9(3), 6-31. https://doi.org/10.46687/QETZ7460. 


\section{Introduction}

Today, the research and theoretical popularity of group work cannot be easily disputed. In education, for instance, group work constitutes the mainstay of many teaching approaches and developmental practices, including cooperative learning and collaborative learning, whose cognitive, affective, and social gains are well received by many empirical studies, though mostly experimental (Tamimy, 2019). Although the effectiveness of group work is well documented by experimental research, it is of limited, if not ineffective, classroom use (Buchs, Filippou, Pulfrey \& Volpe, 2017; Mulisa \& Mekonnen, 2019; Abramczyk \& Jurkowski, 2020), so factors molding the classroom use of it should be studied (Inns \& Slavin, 2018). Among them, a factor which has newly been acquiesced to influence group work is culture (Ghahraman \& Tamimy, 2017; Ghaith, 2018; Inns \& Slavin, 2018; Le, Janssen, \& Wubbels, 2018; Tamimy, 2019), so its scrutiny is deemed necessary to the extent that Inns and Slavin (2018, p. $250)$ rightly aver that 'it is important to understand how cooperative methods interact with cultural contexts and norms' and Ghaith (2018) recommends further research 'to investigate the teacher-related and context-specific factors that impact cooperative learning implementation in various international and cultural settings' (p. 401). Similarly, Hennebry and Fordyce (2018) consider the scrutiny of the role of culture in group work essential.

Despite its irrefutable role, not so many studies have explicitly focused on the cultural factors and their potential interplay with group work (Ghahraman \& Tamimy, 2017; Hennebry \& Fordyce, 2018; Tamimy, 2019) and interestingly, those few studies (e.g., Nguyen, Elliott, Terlouw, \& Pilot, 2009; Nguyen, Terlouw, \& Pilot, 2005, 2012; Thanh, 2014) which tapped into the relations between culture and cooperation are mostly concerned with what they call East Asian cultures and neglected American culture as they provided stereotypical findings by considering impliedly educational group work more suitable for the West, with no empirical investigation of it.

Scholarship on the broader realm of culture itself faces studies on culture and group work with a methodological challenge. The quantitative research such as the honorable works of Hofstede (1986) and House, Hanges, Javidan, Dorfman, and Gupta (2004), though conducted rigorously, are criticized for unduly aggregating individual-level responses to country means for all aspects of life (Schwartz, 2011) or offering essentializing images (Atkinson \& Sohn, 2013). The limitations of the quantitative study of culture impelled research to look into culture from the bottom-up by drawing upon qualitative methodologies so that a more realistic image of the culture can be depicted (Atkinson \& Sohn, 2013), but conducting emic research on such a large scale as a nation would be daunting, if not impossible. In response to this dilemma, rigor and manageability of etic approaches can be reconciled with richness of the emic ones, through a 
promising method like Cultural Linguistics (Sharifian, 2017) or what Tamimy (2019) recommends, which extract culture specific measures from inherently integrated data like proverbs, rather than integrating the individual measures (Schwartz, 2011).

Overall, this introduction suggested that although group work and culture have undeniable ties, their relations have been relatively overlooked. It was also mentioned that the trade-off between the manageability of quantitative methods and the lure of nationwide ethnographies is not unbearable and can be reconciled by the newly emerging approaches such as cultural linguistics (Sharifian, 2017), not yet extensively drawn up. Hence, this study is compelled to investigate proverbs prevalent in American English to uncover (a) how American culture, represented in proverbs, would treat group work, (b) what underlying conceptual metaphors to group work American culture is composed of, and (c) what possible psychosocial causes for such cultural attitudes to group works can be found, so that neither the bottom-up approaches to the study of culture, recommended for their strength, are disregarded nor the American English languaculture is bundled under stereotypical indefinite concepts like the West, which are far below the explanatory adequacy for cross-cultural research.

The move towards the study of culture as represented in proverbs is reasonable and timely in the light of the fact that current quantitative endeavors to cross-cultural study, mostly based on aggregated individual values, are facing challenges, so proverbs are recommended as an appropriate alternative for the study of culture (Schwartz, 2011). Such work would also counteract the limited view to crosscultural research, which maintains that ethnographic research using proverbs cannot serve the scientific study of cultural commonalities and variation (e.g., Minkov, 2013), and in response to the call of Sharifian (2017) would draw more attention to the merits of the application of Cultural Linguistics to research on social, psychological, and educational issues. Moreover, this study would offset the overlooked status of research on such an essential element of social interaction as proverbs (Goddard \& Wierzbicka, 2014). Besides, this study can inform cross-cultural competence, required for better local and international functioning (Chung, 2019), not only by bringing about the flexibility to use cultural tools, but also by contributing to the appropriate selection of means and goals (Chiu \& Shi, 2019).

\section{Proverbs and Culture}

Before proceeding to more details about the method of this study, it is worth to ruminate upon the cultural informativeness of proverbs from different perspectives. Cognitive linguistically, meaning making systems including conceptual metaphors, clearly instantiated in proverbs (Pang, 2014), are shared by a group of people, so they are basically cultural or at least, imbued with 
cultural tone (Kövecses, 2015). In fact, conceptual metaphors map different conceptual domains in the human minds and reflect human experiences (Croft $\&$ Cruse, 2004). Among them, some like those expressed in everyday proverbs are highly conventionalized, in comparison to novel creations (technically called image metaphors) (Sharifian, 2017), because of 'their cognitive significance, which in turn is grounded in human experience' (Croft \& Cruse, 2004, p. 195). Accordingly, proverbs can be seen as a site wherein the conventionalized conceptual metaphors constituting the culturality, can play out (Kövecses, 2015). In fact, as Yu (2015) observed, idiomatic expressions like proverbs are cultural sentiments and 'the way humans think and talk cannot escape the impact of their physical and cultural environment, which constitutes human experience in a fundamental way' (p. 235). Manakin (2015) noted that proverbs are 'the best demonstration of how people encode the world in their mental representations, that is, as the inner forms of words' (p. 113).

Cultural Linguistics maintains that cognition is not confined to the demarcated minds of the individuals, rather it is the outgrowth of the interactions with others and the world, so it is cultural, i.e., characteristic of a cultural group (Sharifian, 2011, 2017). The individuals, interacting with each other, might contribute to cultural cognition and simultaneously are affected by it as an overarching phenomenon (Sharifian, 2017). Language is of consequential significance to cultural cognition because it is 'a primary mechanism for 'storing' and communicating cultural cognition, acting both as a memory bank and a fluid vehicle for the (re-)transmission of cultural cognition' (Sharifian, 2017, p. 5). Thus, language includes culturally constructed conceptualizations, which reflect shared experiences (Sharifian, 2011, 2017). The relations between cultural conceptualizations and language can be explained using different analytical tools including cultural conceptual metaphors, which represent how different concepts are conceived in a culture (Sharifian, 2017). Proverbs are an aspect of language, which clearly mirror the intimate relation between language and culture (Fiedler, 2016).

From the Vygotskian sociocultural point of view, human cultures create and use concepts to operate and think about the world, and these concepts, usually linguistically represented, are inherited from one generation to another (Lantolf \& Poehner, 2014), so cultures with disparate conceptual categories, which can be considerably expressed in intergenerational linguistic symbols like proverbs, 'should be expected to perceive and therefore think about the world differently from other cultures' (Lantolf \& Poehner, 2014, p. 10). Moreover, ethnopragmatics, which is an endeavor to explain the language use in terms of social and cultural values (for more see, Goddard \& Ye, 2015), highly values proverbs because they, alike cultural key words, provide 'culture-rich and translation-resistant words that occupy focal points in cultural ways of thinking, acting, feeling, and speaking' (Goddard \& Ye, 2015, p. 69). And finally, phraseologically, there is 
no gainsaying that worldviews are constituted of some underlying assumptions, among other things, that can be articulated in folk capsules like proverbs, originating from recurrent experiences and observations (Mieder, 2007).

\section{Method}

The design of this research, which uses proverbs to fathom the cultural attitudes to group work, can be seen as straddling content analysis, linguistic ethnography, Cultural Linguistics and case study, but it seems to be more akin to a linguistic ethnographic case study with special attention to Cultural Linguistics (Tamimy, 2019) because it focuses on one bounded cultural group, i.e., American culture (Lodico, Spaulding, \& Voegtle, 2010), and employs linguistic means, viz., discourse analysis and conceptual metaphor analysis, for the enquiry into the cultural imports of proverbs commonly used in American English (Sharifian, 2017; Slembrouck, 2020; Tusting, 2020). It must be pointed out that conceptual metaphors are mental mappings between different conceptual domains, so the human conceptual system is almost all metaphorical (Kövecses, 2020). They not only enable one to understand concepts and experiences in terms of the simpler ones (Lakoff, 1993; Kövecses, 2020), but also construct the reality and suggest the worldviews by picking a specific metaphor among all potentialities (Kövecses, 2020). Indeed, the fact that any given metaphor, in comparison to the other alternatives, is singled out to talk about a phenomenon is itself meaningful (Kövecses, 2020). In fact, this study, in its three layered procedure, reconciles content analysis, ethnography, paremiology, and Cultural Linguistics so it might answer Sharifian's (2017) call for contribution of other methods to the treasury of research methods in Cultural Linguistics. As a Cultural Linguistic study, it takes an area of activity, i.e., group work, and examines the cultural cognitive metaphors underlying in proverbs about it (see Sharifian, 2017, pp. 41-50).

\section{Data Collection}

To untangle the cultural attitudes laden with Anglo-American proverbs regarding group work, every single entry of Oxford Dictionary of Proverbs, edited by Speake (2015), containing over 2500 entries, was taken as the pool from which the proverbs related to interpersonal behavior and group work were selected. Speake (2015) was chosen as the source of proverbs not only because it is the most recently published collection of English proverbs, contributive to the currency of its entries, but also because it, unlike many other collections of proverbs (Doyle, 2007), is relatively dictionary like and in many cases includes authoritative definitions. This could increase the credibility of interpretation of the proverbs by the researcher.

In response to the doubt how English-language proverbs, compiled in Speake (2015), can provide information about American culture, it should be mentioned 
that before being fed into the analysis, the proverbs' prevalence, as described below, was checked using the Corpus of Contemporary American English (COCA), whose data come from the American speakers, so it can be argued that 'while they [the proverbs] are not of American origin, they are certainly in common use in North America. They are thus American proverbs in that the population uses them frequently as concisely, expressed, traditional bits of wisdom' (Mieder, Kingsbury, \& Harder, 1992, p. xi), so they can be reflective of American culture.

\section{Duplicates Removal}

Screening 2500 proverbs for instantiations of interpersonal relations, defined as the explicit or implicated inclusion of two or more people in source form of the proverb or its target meaning, yielded to a 56-item list, which as Tamimy (2019) cautioned and Speake (2015) noted, could have included duplicates. To ensure no duplicates can dilute the data and in turn, the analysis, the duplicate detection algorithm recommended by Tamimy (2019), which includes both fuzzy comparisons based on word-level tokenized elements and linguistic evaluations, was implemented, and two items ('EVERY man for himself, and devil take the hindmost' and 'EVERY man for himself, and God for us all') were removed. Accordingly, the corpus contained 54 distinct records ${ }^{1}$.

\section{Currency Check}

Aside from the duplicates, the currency of the proverbs could be a serious issue because, on the one hand, the publication date can provide no warrant of the prevalence of the proverbs, partly because proverb dictionaries largely rely on text- based approaches to data collection (Doyle, 2007), and on the other hand, outdated and uncommon proverbs cannot offer a true reflection of the present-day culture. To obviate such a threat, Tamimy (2019) advanced a psychometrically credible rating-scale through which the judgments of speakers about the currency of proverbs could be solicited. However, such an approach suffers some limitations because it is attitudinal, indirect, and based on the judgment of an incomprehensive number of people. To compensate for these caveats, this study drew upon corpus linguistics to examine directly how current any proverb is. Each proverb was looked up in March, 2020 version of Corpus of Contemporary American English (COCA), containing about 1 billion words of different genera used since 1990. As a liberal criterion for currency, at least one instance of use should be recorded in COCA for each proverb in the current decade, as of 2010 till 2019. Accordingly, 12 proverbs which deemed to

1. The shortlist is not reported here because it can increase the manuscript's word count, usually constrained by the scientific journals. 
be outdated were dropped from the corpus, and the shortlisted data included 42 proverbs of appropriate currency (Appendix A).

\section{Data Analysis}

\section{The First Layer}

The proverbs of appropriate currency underwent three levels of analysis. First, they were deductively coded in terms of cooperation, individualism and competition, corresponding respectively to positive interdependence, zero interdependence, and negative interdependence, which constitute the main types of group behavior (Hogg \& Levine, 2010; Johnson \& Johnson, 2017). Cooperation is a situation of positive interdependence in which individuals trust and help each other because their gain is contingent upon the group's gain (Hogg \& Levine, 2010; Johnson \& Johnson, 2017). Individualism is a status of independence, falling between cooperation and competition, in which people have no regards, be it positive or negative, for the others' outcomes, and strive only for their own personal goal (Hogg \& Levine, 2010; Johnson \& Johnson, 2017). Competition, as a an instance of negative interdependence, is to gain advantage necessarily at the cost of others' loss (Hogg \& Levine, 2010; Johnson \& Johnson, 2017).

A fourth category of Not Applicable had also been added to the codes, so that raters are not biased to provide harmonious judgments. Three distinct raters who, because of their experience and education (Table 1), were relatively familiar with English proverbs and semiotics independently and blindly coded each proverb. The interrater reliability (Fleiss's Kappa $=.82$ ) was found to be high enough to buttress the dependability of the analysis. For seven cases, disagreement was observed, which was resolved through majority criterion. Then, the proverbs were clustered correspondingly and the frequency count of each category was calculated.

Table 1.

Raters' Demographics

\begin{tabular}{l|l|l|l|l} 
Pseudonym & Sex & Age & Major & Education \\
\hline C1 & Male & 32 & Applied Linguistics/TESOL & Ph.D. candidate \\
\hline C2 & Male & 55 & Western Philosophy & Ph.D. \\
\hline C3 & Male & 37 & Translation Studies & Master's
\end{tabular}




\section{The Second Layer}

Lemghari (2019) showed that proverbs are metaphor dependent, so at the second level of the analysis, the proverbs were examined in terms of their idealized cognitive models (ICMs) so that it is unraveled (a) whether there are any overarching conceptualizations which can account for the different proverbs about group functioning or the proverbs are more like a sporadic miscellany, and (b) what worldview these conceptualizations would indicate. This is significant because it can triangulate the numerically summarized findings of the first layer of the analysis. ICMs can be defined as 'not all-encompassing, but representative, genetically driven, and culturally grounded units of thought in the subconscious of the native(-like) speakers of a language which...inform their world views and correspondingly, their actions' (Tamimy, 2019, p. 429). ICMs, relatively similar to Wierzbicka's cultural scripts, rest on the premise that 'the meaning of an expression represents the conceptualizer's desire to construe the relevant cognitive domains in a specific way' (Achard \& Niemeier, 2003, p. 3), so ICMs can show the overarching worldview of people to different phenomena (Kövecses, 2005; Pang, 2014). Cognitive domains such as ICMs can 'provide enhanced opportunities to demonstrate links between discourse practices and sociocultural values, as embodied in cultural key words, value terms, proverbs, etc.' (Goddard, 2003, p. 146). Expatiating a bit more on the link between conceptual metaphors and culture, Kövecses (2005) rightly observes that the way primary metaphors combine to form complex metaphor conceptualization, representing human thought deeply, is cultural, so understanding what cultural differences exist between ICM's can boil down to an understanding of the crosscultural variations in human thoughts and behaviors.

\section{The Third Layer}

The proverbs, at the third layer of the analysis, were first inductively coded to see through what psychosocial factors culture can most likely influence the cultural attitudes to group behavior, characterized as cooperation, individualism, and competition. Then the results of the inductive coding were provided to a second rater who was asked to code the proverbs based on the categories provided or devise his own codes. The first coder was a Ph.D. candidate and the latter was a doctorate holder in applied linguistics/TESOL. The interrater agreement was high enough (Cohen's kappa $=.83$ ). Out of 35 cases, there were 30 agreements and five disagreements. The disagreements were discussed and for three of them a composite factor, i.e., independent self-construal and conflict, involving the ideas of the two raters was chosen and for the other two one rater accept the explanations of the other one. There is no need to remind that the data and coding are reported in this paper, so they are publically available for readers' judgment and evaluation, so no serious room for the dependability of the analysis would remain (Lodico et al., 2010). 


\section{Findings and Discussion}

\section{General Attitude}

The proverbs were examined to see what attitude to group work American culture, at least in its heart as represented by the proverbs, might have by coding them either as suggestive of cooperation, competition, individualism, or irrelevant. As a result, seven proverbs were removed for being irrelevant to group work. The results reported henceforth are based on the analyses conducted on the rest of the proverbs $(N=35)$. The findings, depicted in Figure 1 and Table 2, suggest that American culture as expressed in proverbs has a borderline attitude to group work because although it substantially welcomes cooperative behavior (cooperation $=54 \%$ ), it has comparative potentiality, though to a lesser extent, for non-cooperativeness $(46 \%)$, materializing either as individualism $(23 \%)$ or competitiveness (23\%). Surprisingly, this finding, in line with that of Y. Takano and Osaka (2018), problematizes a large body of previous literature which considers American culture to be individualistic and in turn, less cooperation friendly (e.g., Hofstede, 1980; Kubota, 2001; Gudykunst, 2003; Lustig \& Koester, 2010; Samovar, Porter, McDaniel \& Roy, 2015). It also supports the arguments of Wong, Wang, and Klann (2018) suggesting that individualism/ collectivism should no longer be taken to evaluate the culturality of behaviors in general (Wong et al., 2018) and group work in particular (Zhou \& Shi, 2011; Ghahraman \& Tamimy, 2017).

This finding when compared with the results of Tamimy (2019) about Iranian people also indicates that there are cross-cultural similarities and differences between Iranian and American culture. According to Tamimy (2019), Iranian culture as depicted in its proverbs is generally individualistic, whereas American culture was shown to be relatively cooperative. Moreover, it is interesting to know that both cultures are to the same extent competitive (cf. Tamimy, 2019), although they have drastic differences in terms of their politics, religion, history, geography, and education. Future studies from various disciplines, can investigate what factors could have eventuated to such similarity and differences. Moreover, the differences and similarities between the American and those reported for the Iranian culture's attitude to group work (see Tamimy, 2019),

contained in their proverbs, corroborate the previous arguments for the effect of culture on group work (Liang, 2004; Sharan, 2010; Thanh, 2014; Ghahraman \& Tamimy, 2017; Tamimy, 2019) . 


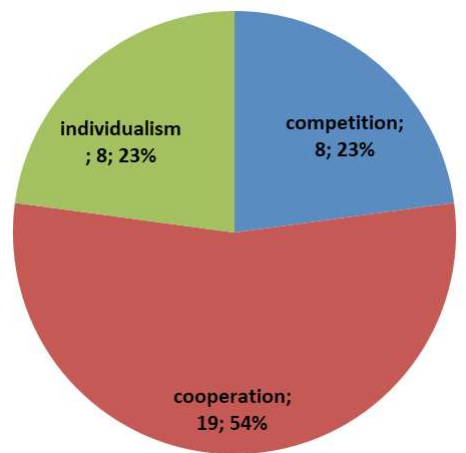

Figure 1. The cultural attitudes to group work

Table 2.

Proverbs and their Cultural Attitude to Group Work

\begin{tabular}{cl}
\hline \multicolumn{1}{c}{ Attitude } & \multicolumn{1}{c}{ Proverb $^{*}$} \\
\hline \multirow{5}{*}{ Competition } & BETTER be envied than pitied. \\
& BIG fish eat little fish. \\
& BUSINESS is war. \\
& EVEIL take the hindmost. \\
& If you are not the LEAD dog, the view never changes. \\
& NO harm, no foul. \\
& One man's LOSS is another man's gain. \\
\hline \multirow{5}{*}{ Cooperation } & $\begin{array}{l}\text { A HOUSE divided cannot stand. } \\
\text { A TROUBLE/Problem shared is a trouble halved. } \\
\text { EVERY little helps. } \\
\text { He GIVES twice who gives quickly. } \\
\text { If every man would SWEEP his own doorstep the city } \\
\text { would soon be clean. }\end{array}$ \\
\cline { 2 - 3 } & $\begin{array}{l}\text { It takes a whole VILLAGE to bring up a child. } \\
\text { It takes TWO to tango. } \\
\text { LOVE begets love. } \\
\text { MANY hands make light work. } \\
\text { One hand washes the other (and both wash the face). } \\
\text { POLITICS makes strange bedfellows. } \\
\text { The MORE the merrier. } \\
\text { There is HONOUR among thieves. } \\
\text { There is SAFETY in numbers. } \\
\text { TWO heads are better than one. } \\
\text { UNION/Unity is strength. } \\
\text { UNITED we stand, divided we fall. } \\
\text { You don't get SOMETHING for nothing. } \\
\text { You SCRATCH my back, I'll scratch yours. }\end{array}$ \\
\hline
\end{tabular}




\begin{tabular}{c|l}
\hline \multicolumn{1}{c}{ Attitude } & \multicolumn{1}{c}{ Proverb $^{*}$} \\
\hline & Every TUB must stand on its own bottom. \\
God helps those who help themselves. \\
GOOD fences make good neighbors. \\
Individualism \\
He TRAVELS fastest who travels alone. \\
Neither a BORROWER nor a lender be. \\
One HAND for yourself and one for the ship. \\
TOO many cooks spoil the broth. \\
What you HAVE, hold.
\end{tabular}

Note. Words in CAPITAL, are head words based on which Oxford Dictionary of Proverbs is sorted.

\section{Idealized Cognitive Models}

Moreover, different proverbs were analyzed in terms of their underpinning idealized cognitive models (ICMs), 'encyclopedic knowledge... that provide scenarios or action plans for individuals of how to interpret speech situations and behave in a particular circumstance' (Kecskés, 2014, p. 82). The ICMs underlying the proverbs can be subsumed within the domains of cooperation, competition, and individualism (see Kövecses, 2017), so it can be inferred that English-language proverbs used in America truly reflect different cultural attitudes to group work, otherwise they would have formed a chaotic miscellany. The results, represented in Table 3, suggest that competition in American culture is not monolithic and is at least of two kinds with varying degrees of severity, moderate and extremely high because there were two ICMs of LIFE IS RACE and LIFE IS WAR for the proverbs talking of competition.

The ICMs underlying proverbs suggestive of cooperation, represented in Table 3, show that there are different incentives for cooperativeness, so it is again corroborated that a simplistic term like collectivism cannot account for group functioning (Wong et al., 2018; Tamimy, 2019). Compared with the ICMs Tamimy (2019) found underlying Iranian proverbs, the ICMs unearthed here for the American culture also point out that there are similarities and differences between the ICMs present in Persian and American English with regard to cooperation (see, Tamimy, 2019). For example, NUMBERS ARE POWER was common between the American attitudes towards cooperation and those of the Iranian, reported by Tamimy (2019), whereas LIFE IS RECIPROCAL was exclusive to the American culture, so on the one hand, it can be inferred that group work is cultural, and on the other hand, it can be figured out that ICMs are cultural with both universalities and variations (Kövecses, 2005; Sharifian, 2017). Cross-culturally similar conceptual metaphors are posed to be a sign of cognitive and experiential significance (Croft \& Cruse, 2004), so cross-culturally similar ICMs, i.e., NUMBERS ARE POWER and COMPANY IS TROUBLE, indicate 
that cooperation and individual performance have been of great cognitive significance, originating from the humans' long lived engagement with them. Consequently, it can be argued if ICMs of cooperation and individualism do not exist together in a linguaculture, that culture can be truly considered either collectivistic or individualistic. Future studies are encouraged to see if there is any linguaculture in which either of the ICMs driving cooperation or individualism are mutually exclusive.

As Table 3 represents, the ICMs underlying the proverbs constitute a heterogeneous set. This heterogeneity is unsurprising because cultures are not monolithic wholes and do include differences and even, paradoxes (Archer, 1985). According to Lemghari (2019), this is quite natural as conceptualization underlying proverbs are frame-based and the frame, given its complexity, can include various sub-frames. In fact, 'since metaphors are conceptual in nature, it does not sound paradoxical that antonymy and synonymy may co-occur within the same frame or sub-frame' (Lemghari, 2019, p. 181). Moreover, this finding is among the few reports which empirically shore up Fischer's (2008) sociological reflection, suggesting that American culture is substantially cooperative despite its undeniable individualism. This might also designate the heterogeneity of American culture with regard to the attitudes to group work.

Table 3.

The Proverbs and their Respective ICMs

\begin{tabular}{|c|c|c|}
\hline & Proverb & ICM \\
\hline \multirow{8}{*}{ 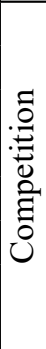 } & BETTER be envied than pitied. & \multirow[t]{3}{*}{ life is race } \\
\hline & If you are not the LEAD dog, the view never changes. & \\
\hline & NO harm, no foul. & \\
\hline & BIG fish eat little fish. & \multirow[t]{5}{*}{ life is war } \\
\hline & BUSINESS is war. & \\
\hline & DEVIL take the hindmost. & \\
\hline & EVERY man for himself. & \\
\hline & One man's LOSS is another man's gain. & \\
\hline
\end{tabular}




\begin{tabular}{|c|c|c|}
\hline \multirow{19}{*}{ 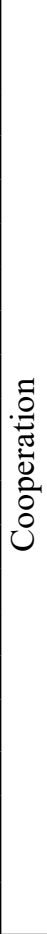 } & POLITICS makes strange bedfellows. & $\begin{array}{l}\text { life is a force which } \\
\text { brings people together }\end{array}$ \\
\hline & LOVE begets love. & \multirow[t]{4}{*}{ life is reciprocal } \\
\hline & One hand washes the other (and both wash the face). & \\
\hline & You don't get SOMETHING for nothing. & \\
\hline & You SCRATCH my back, I'll scratch yours. & \\
\hline & A HOUSE divided cannot stand. & \multirow[t]{12}{*}{ numbers are power } \\
\hline & A TROUBLE/Problem shared is a trouble halved. & \\
\hline & EVERY little helps. & \\
\hline & $\begin{array}{l}\text { If every man would SWEEP his own doorstep the city } \\
\text { would soon be clean. }\end{array}$ & \\
\hline & It takes a whole VILLAGE to bring up a child. & \\
\hline & It takes TWO to tango. & \\
\hline & MANY hands make light work. & \\
\hline & \begin{tabular}{|l} 
The MORE the merrier. \\
\end{tabular} & \\
\hline & There is SAFETY in numbers. & \\
\hline & TWO heads are better than one. & \\
\hline & UNION/Unity is strength. & \\
\hline & UNITED we stand, divided we fall. & \\
\hline & He GIVES twice who gives quickly. & \multirow[t]{2}{*}{ people are courteous } \\
\hline & There is HONOUR among thieves. & \\
\hline \multirow{8}{*}{ 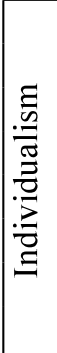 } & GOOD fences make good neighbors. & \multirow[t]{4}{*}{ company is trouble } \\
\hline & He TRAVELS fastest who travels alone. & \\
\hline & Neither a BORROWER nor a lender be. & \\
\hline & TOO many cooks spoil the broth. & \\
\hline & Every TUB must stand on its own bottom. & \multirow[t]{4}{*}{ selfness is survival } \\
\hline & God helps those who help themselves. & \\
\hline & One HAND for yourself and one for the ship. & \\
\hline & What you HAVE, hold. & \\
\hline
\end{tabular}

\section{Psychosocial Factors}

The proverbs were finally scrutinized in terms of the culturally-grounded psychosocial factors which could have promoted different attitudes to group work. The analysis suggests that the proverbs talking of a liking for competition were psychosocially inspired by two factors, egoism and consequentialism (Table 4). Although there is definitional controversy about egoism, in the modern time, egoism can be read as 'the excessive concern with one's own pleasure or advantage at the expense of community well-being' (Weigel, Hessing \& Elffers, 1999 , p. 349) and it is believed to have the potential to end in antisocial behavior including unhealthy competition (van Vugt, 2010; Johnson \& Johnson, 2017), probably through its effect on group communication (Johnson \& Johnson, 2017). 
The proverb, NO harm, no foul, suggested that consequentialism - the belief that consequences, rather than the essence of action, are of moral, political and social matter (Price, 2008) - can impact on competition in the sense that actions securing one's own personal benefit, even if not essentially just like competition, are allowed as long as their outcome does not explicitly harm others. In other words, it can be argued that consequentialism permits for the securing of ones' own benefit at the cost of the others' loss, 'harm' as the proverb signifies. This phenomenon observed in the proverbs is in line with psychological discoveries on the negative relations between consequentialism and cooperation (Everett, Pizarro \& Crockett, 2016).

Table 4. Psychosocial Factors Driving Proverbs Indicative of Competition

\begin{tabular}{|l|l|}
\hline Proverb & Psychosocial Factor \\
\hline EVERY man for himself. & egoism \\
BUSINESS is war. & \\
DEVIL take the hindmost. & \\
BIG fish eat little fish. & \\
BETTER be envied than pitied. & \\
One man's LOSS is another man's gain. & \\
If you are not the LEAD dog, the view never changes. & \\
\hline NO harm, no foul! & consequentialism \\
\hline
\end{tabular}

The individualistic cultural attitude of American English speakers discovered through the discourse analysis done in the first layer of the data analysis and the conceptual metaphor analysis conducted in the second layer was observed to be instigated by distrust, egoism, independent self-construal and deviance (Table 5). There is no need to mention that distrust in American culture, as similarly reported for the Iranian culture (Tamimy, 2019), can muddy the waters of cooperation either by hindering communication (Johnson \& Johnson, 2017; Komori-Glatz, 2018), or by dwindling cohesion among members (Forsyth, 2018). Besides, the positive impact of distrust on individualism can explain why future orientation, among its constituents is distrust, has negative relation with constructive conflict (Alavi \& Tamimy, 2014), an essential element for cooperation (Decuyper, Dochy, \& Van den Bossche, 2010).

Independent self-construal was also found to be able to influence individualism (Table 5). It is the definition of oneself as a totally independent agent who would cognitively see the world in terms of unique objects, and behaviorally prioritize personal gains as life satisfaction (Gardner \& Slotter, 2007). Interestingly, this finding based on paremiological analysis not only vindicates the previous quantitative psychological research using social dilemmas which documented a negative relation between independent self-construal and cooperation (e.g., 
Utz, 2004), but also hones them by specifying what independent self-construal might possibly influence, that is, individualism, not competition.

The existence of egoism among the factors contributing to individualism, evident in Table 5, can raise the question how it can engender both competition, as previously discussed, and individualism. The response lies in the degree of egoism available, which might align with multiplicity of philosophical conceptions of egoism. Egoism that engenders competition is of greater severity and one which culminates in individualism, as evident in one hand for yourself and one for the ship' and hold what you have, of moderate degree. The former might correspond to psychological egoism and the latter to hedonistic egoism (see Feinberg, 2013; Rachels, 2013). This differential influence cautions social studies like Tamimy (2019) to refrain from the monolithic treatment of egoism and necessitates further research to examine the potential differences these two types of egoism can bring to social phenomena.

Diffusion of responsibility and conflict among members could contribute to individualism, as instantiated in 'too many cooks spoil the broth' (Table 5). Diffusion of responsibility denotes when more than one person encounters something or is responsible for it, each individual member feels less obligation to interfere, or even if $s /$ he interferes, less is invested (Darley, 2007). Caution needs to be exercised not to reduce the psychosocial antecedents of this proverb either to the diffusion of responsibility or conflict, as Tamimy (2019) mistakenly did, because these factors hand in hand explain the meaning underlying this proverb and its respective ICM, i.e., COMPANY IS TROUBLE.

Table 5. Psychosocial Factors Driving Proverbs Indicative of Individualism

\begin{tabular}{|l|l|}
\hline Proverb & Psychosocial Factor \\
\hline $\begin{array}{l}\text { GOOD fences make good neighbors. } \\
\text { Neither a BORROWER nor a lender be! } \\
\text { He TRAVELS fastest who travels alone. }\end{array}$ & distrust \\
\hline $\begin{array}{l}\text { What you HAVE, hold! } \\
\text { One HAND for yourself and one for the ship. }\end{array}$ & egoism \\
\hline $\begin{array}{l}\text { God helps those who help themselves. } \\
\text { Every TUB must stand on its own bottom. }\end{array}$ & $\begin{array}{l}\text { independent self-construal } \\
\text { and conflict }\end{array}$ \\
\hline TOO many cooks spoil the broth. & $\begin{array}{l}\text { Diffusion of responsibility } \\
\text { and destructive conflict }\end{array}$ \\
\hline
\end{tabular}

A considerable, though not firmly predominating, penchant for cooperation was observed in American culture, as the first and second layer of data analysis showed. The third layer of the analysis unraveled that, as represented in Table 6 , this inclination could be explained in terms of psychosocial factors such as altruism, cohesion, reciprocal altruism, and socially shared cognition. 
Altruism, as an act of help to alleviate the others' difficulties, can be almost free from expectation for return, referred to as true altruism (Reis, 2007), or can include an anticipation for repayment in an array of forms, referred to as reciprocal or egoistic altruism (Pizarro, 2007). The positive relation proverbs show between altruism and cooperation paremiologically supports previous quantitative research in this regard, suggestive of a solid link (e.g., Pizarro, 2007; Reis, 2007; Mezzich, 2011; Takano, Wada, \& Fukuda, 2016). However, this must not lead to the negligence of the culturality of such a link (Tamimy, 2019) because while this paper on Anglo-American proverbs and culture talks of the positive relationship between reciprocal altruism and cooperation, Tamimy (2019) through his investigation of the Persian proverbs contradictorily reported a relation between reciprocal altruism and non-cooperation. $f$ Besides, this relation can provide a paremiological and cultural support for the empathyaltruism hypothesis by highlighting that, according to 'A trouble/ problem shared is a trouble halved', a problem is first shared, then empathy is evoked, and as a result it is halved probably because it has ended in altruistic behavior.

Table 6.

Psychosocial Factors Driving Proverbs Indicative of Cooperation

\begin{tabular}{|l|l|}
\hline Proverb & Psychosocial Factor \\
\hline One hand washes the other (and both wash the face). & altruism \\
There is HONOUR among thieves. & \\
A TROUBLE/Problem shared is a trouble halved. \\
It takes a whole VILLAGE to bring up a child. \\
He GIVES twice who gives quickly. \\
If every man would SWEEP his own doorstep the \\
city would soon be clean. & \\
\hline There is SAFETY in numbers. & \\
It takes TWO to tango. & cohesion \\
The MORE the merrier. & \\
A HOUSE divided cannot stand. & \\
MANY hands make light work. & \\
EVERY little helps. & \\
UNITED we stand, divided we fall. & \\
UNION/Unity is strength. & \\
\hline You SCRATCH my back, I'll scratch yours. & reciprocal altruism \\
LOVE begets love. & \\
You don't get SOMETHING for nothing. & socially shared cogni- \\
\hline TWO heads are better than one. & Nion \\
\hline POLITICS makes strange bedfellows. & \\
\hline
\end{tabular}


American culture's propensity for cooperation is also motivated by cohesion and socially shared cognition (Table 6). This finding corroborates the definite premise that cohesion, the driving force which keeps the group members together to pursue a shared goal, can boil down to cooperativeness (Carron \& Burke, 2010; Johnson \& Johnson, 2017). It also suggests that the differentiation between task and social cohesion is not just a quantitative interpretation arrived at through statistical procedures like principal component analysis, rather a reality, probably cultural, because there are proverbs which clearly instantiate task cohesion (e.g., many hands make light work, every little helps, and union/ unity is strength) and proverbs which represent social cohesion (e.g., the more the merrier, united we stand, divided we fall, and there is safety in numbers). Future cultural studies using proverbs can be advised to investigate how cohesion threatening factors like jealousy and group thinking, and extreme status of harmony among members (Turner \& Pratkanis, 2010), can end in non-cooperativeness by enquiring into proverbs about jealousy and harmony. Additionally, 'two heads are better than one', on the one hand, bespeaks clearly of the positive link between socially shared cognition and cooperation, quantitative research reported of (e.g.,Van den Bossche, Gijselaers, Segers, \& Kirschner, 2006).

\section{Conclusion}

The ties between culture and group work have just come to receive burgeoning attention, but such a move can neither withstand the relatively withering criticisms targeting mainstream quantitative cross-cultural research, nor it can meet the manageability demands of bottom-up approaches, if are to be implemented on large scales. Moreover, some verdicts, roughly stereotypical, about the cooperation-unfriendliness of Western culture fueled by the rabid interpretations of post-colonialism can be heard, which can boil down to the further inattention to the role of culture (Tamimy, 2019). Addressing these issues, this study drew upon paremiological ethnography to figure out (a) what attitude American culture, as a non-stereotypical counterpart to Western culture, can have towards group work, (b) what worldviews, as expressed in ICMs underlying the proverbs, American culture has towards group work, and (c) what culturally grounded psychosocial factors, represented in proverbs, drive such attitudes towards group work. Accordingly, Anglo-American proverbs about interpersonal behavior were collected, filtered for duplicates, went through currency checks, and analyzed at three different levels of discourse, metaphor, and content.

As a result, it was revealed that American culture, despite the common belief, has a marginal preference for cooperation in comparison to non-cooperation encompassing of equal tendency for individualism and competitiveness. The 
findings of metaphor analysis also disclosed that American culture is composed of heterogeneous worldviews which overall imply the American culture's embracement of cooperation. The content analysis traced what psychosocial factors could have culturally mold the American speakers' attitudes to group work and thereupon, egoism and consequentialism were witnessed to incite competitiveness. Cohesion, altruism, and socially shared cognition were seen to fashion cooperativeness, and individualism was observed to be regulated by distrust, ethical egoism, independent self-construal, and conflict.

Altogether, these findings offer a few general insights. First, it can be understood that, despite the untenable arguments of Minkov's (2013), proverbs can scientifically and empirically inform cross-cultural research. Second, it was portrayed that stereotyping American culture, under the broad label of West, as individualistic and competitive is at odds with the cultural reality and indeed, such illusions might originate from the very fact that culture, regardless of its convolutions, is usually identified with economy. Third, it was cognitive linguistically vindicated that conceptual metaphors are both of universal and cultural specificity (Kövecses, 2005). Fourth, it was found that group work and the interplay of the psychosocial factors which induce different attitudes to group work are cultural, at least partially, and thus, intercultural education/psychology/ communication should give a higher weight to the intersection of culture and language, especially cognitive cultural conceptualizations (Sharifian, 2014). Finally, the factors, whether positive or negative, which can have bearing on cooperation were identified and based on this knowledge, informed decisions for the effectiveness improvement of group work can be made.

It must be mentioned that this study suffered a few limitations and delimitations. First, it only opted for a synchronic scrutiny of proverbs for culture, while proverbs might undergo meaning change, however slow, which can show the cultural evolution of a society (Pang, 2014). Future works can look into the cultural journeys of people by taking a diachronic approach to the study of proverbs. Second, this research, due to its focus, could not make a distinction between the dialectical origin and prevalence of different proverbs, so the upcoming investigations can be recommended to examine if there are any dialectical differences with regards to the prevalence of proverbs and if so, how they might have a bearing on culture. Last, future works are recommended to examine the trustworthiness of the findings of this study through replications using other methodologies, so that the case for the analytical generalization of the findings is provided (Firestone, 1993).

\section{References:}

Abramczyk, A., \& Jurkowski, S. (2020). Cooperative learning as an evidencebased teaching strategy: what teachers know, believe, and how they use it. 
Journal of Education for Teaching, 46(3), 296-308. https://doi.org/10.1080/02 607476.2020.1733402.

Achard, M., \& Niemeier, S. (2003). Introduction: Cognitive linguistics, language acquisition, and pedagogy. In M. Achard \& S. Niemeier (Eds.), Cognitive linguistics, second language acquisition, and foreign language teaching (pp. 1-12). Berlin: Mouton de Gruyter.

Alavi, S. M., \& Tamimy, M. (2014). An investigation into the role of culture within cooperative learning: The cognitive drivers. Journal of Foreign Language Research, 4(2), 341-372.

Archer, M. S. (1985). The myth of cultural integration. The British Journal of Sociology, 36(3), 333-353. https://doi.org/10.2307/590456

Atkinson, D., \& Sohn, J. (2013). Culture from the bottom up. TESOL Quarterly, 47(4), 669-693.

Buchs, C., Filippou, D., Pulfrey, C., \& Volpe, Y.(2017). Challenges for cooperative learning implementation: reports from elementary school teachers. Journal of Education for Teaching, 43(3), 296-306. https://doi.org/10.1080/02607476. 2017.1321673.

Carron, A., \& Burke, S. (2010). Group Cohesiveness. In J. M. Levine \& M. A. Hogg (Eds.), Encyclopedia of Group Processes \& Intergroup Relations (Vol. 1, pp. 316-320). Thousand Oaks, CA: SAGE Publications, Inc.

Chiu, C. y., \& Shi, Y. (2019). Cross-cultural competence. In K. D. Keith (Ed.), Cross-cultural psychology:Contemporary themes and perspectives $\left(2^{\text {nd }} \mathrm{ed}\right.$., pp. 39-55). NJ, USA: Wiley-Blackwell.

Chung, L. C. (2019). Crossing boundaries: Cross-cultural communication. In K. D. Keith (Ed.), Cross-cultural psychology:Contemporary themes and perspectives ( $2^{\text {nd }}$ ed., pp. 375-397). NJ, USA: Wiley-Blackwell.

Croft, W., \& Cruse, D. A. (2004). Cognitive Linguistics. New York: Cambridge University Press.

Darley, J. (2007). Diffusion of responsibility. In R. F. Baumeister \& K. D. Vohs (Eds.), Encyclopedia of social psychology (Vol. 1, pp. 247-248). California, USA: Sage.

Decuyper, S., Dochy, F., \& Van den Bossche, P. (2010). Grasping the dynamic complexity of team learning: An integrative model for effective team learning in organisations. Educational Research Review, 5(2), 111-133. https://doi. org/10.1016/j.edurev.2010.02.002.

Doyle, C. C. (2007). Collections of proverbs and proverb dictionaries: Some historical observations on what's in them and what's not (with a note on current 'gendered' proverbs). In P. Skandera (Ed.), Phraseology and culture in English (pp. 181-204). Berlin: Mouton de Gruyter. 
Everett, J. A. C., Pizarro, D. A., \& Crockett, M. J. (2016). Inference of trustworthiness from intuitive moral judgments. Journal of Experimental Psychology: General, 145(6), 772-787. https://doi.org/10.1037/xge0000165.

Feinberg, J. (2013). Psychological Egoism. In R. Shafer-Landau (Ed.), Ethical theory: An anthology ( $2^{\text {nd }}$ ed., pp. 167-177). MA, USA: Wiley-Blackwell.

Fiedler, A. (2016). Fixed expressions and culture: The idiomatic monkey in common core and West African varieties of English. International Journal of Language and Culture, 3(2), 189-215. https://doi.org/10.1075/ijolc.3.2.03fie.

Firestone, W. A. (1993). Alternative arguments for generalizing from data as applied to qualitative research. Educational researcher, 22(4), 16-23.

Fischer, C. S. (2008). Paradoxes of American Individualism. Sociological Forum, 23(2), 363-372. https://doi.org/10.1111/j.1573-7861.2008.00066.x.

Forsyth, D. R. (2018). Group dynamics ( $7^{\text {th }}$ ed.). MA: Wadsworth, Cengage Learning.

Gardner, W. L., \& Slotter, E. (2007). Independent self-construals. In R. F. Baumeister \& K. D. Vohs (Eds.), Encyclopedia of social psychology (pp. 471-472). California: Sage.

Ghahraman, V., \& Tamimy, M. (2017). The role of culture in cooperative learning. International Journal of Language Studies, 11(2), 89-120.

Ghaith, G. M. (2018). Teacher perceptions of the challenges of implementing concrete and conceptual cooperative learning. Issues in Educational Research, 28(2), 385-404.

Goddard, C. (2003). 'Cultural scripts': A new medium for ethnopragmatic instruction. In M. Achard \& S. Niemeier (Eds.), Cognitive linguistics, second language acquisition, and foreign language teaching (pp. 143-164). Berlin: Mouton de Gruyter.

Goddard, C., \& Wierzbicka, A. (2014). Words and meanings : Lexical semantics across domains, languages, and cultures ( ${ }^{\mathrm{st}} \mathrm{ed}$.). NY, USA.

Goddard, C., \& Ye, Z. (2015). Ethnopragmatics. In F. Sharifian (Ed.), The Routledge handbook of language and culture (pp. 66-84). NY, USA: Routledge.

Gudykunst, W. B. (2003). Cross-cultural and intercultural communication. Thousand Oaks, Calif:: Sage Publications.

Hennebry, M. L., \& Fordyce, K. (2018). Cooperative learning on an international masters. Higher Education Research \& Development, 37(2), 270-284. https:// doi.org/10.1080/07294360.2017.1359150.

Hofstede, G. (1980). Culture's consequences. Beverly Hills, CA: Sage.

Hofstede, G. (1986). Cultural differences in teaching and learning. International Journal of intercultural relations, 10(3), 301-320. 
Hogg, M. A., \& Levine, J. M. (2010). Cooperation and competition. In J. M. Levine \& M. A. Hogg (Eds.), Encyclopedia of group processes \& intergroup. relations (Vol. 1, pp. 155-160). Thousand Oaks, CA: SAGE Publications, Inc.

House, R. J., Hanges, P. J., Javidan, M., Dorfman, P. W., \& Gupta, V. (2004). Culture, leadership, and organizations: The GLOBE study of 62 societies: Sage publications.

Inns, A. J., \& Slavin, R. E. (2018). Cooperative learning:Theoretical foundations and relevance across cultures. In G. A. D. Liem \& D. M. McInerney (Eds.), Big Theories Revisited 2 (pp. 237-266). Charlotte: Information Age PublishingIap.

Johnson, D. W., \& Johnson, F. P. (2017). Joining together:Group theory and group skills (12th ed.). Boston: Pearson.

Kecskés, I. n. (2014). Intercultural pragmatics. Ny, USA: Oxford University Press.

Komori-Glatz, M. (2018). 'Cool my doubt is erased': Constructive disagreement and creating a psychologically safe space in multicultural student teamwork Journal of English as a Lingua Franca (Vol. 7, pp. 285).

Kövecses, Z. (2015). Where metaphors come from: Reconsidering context in metaphor. NY, USA: Oxford University Press.

Kövecses, Z. (2017). Levels of metaphor. Cognitive Linguistics, 28(2), 321-347. https://doi.org/10.1515/cog-2016-0052.

Kövecses, Z. (2020). Extended conceptual metaphor theory. Cambridge, UK: Cambridge University Press.

Kövecses, Z. n. (2005). Metaphor in culture: Universality and variation. Cambridge: Cambridge University Press.

Kubota, R. (2001). Discursive construction of the images of U.S. classrooms. TESOL Quarterly, 35(1), 9-38. https://doi.org/10.2307/3587858.

Lakoff, G. (1993). The contemporary theory of metaphor. In A. Ortony (Ed.), Metaphor and thought (2nd ed., pp. 202-251). New York: Cambridge University Press.

Lantolf, J. P., \& Poehner, M. E. (2014). Sociocultural theory and the pedagogical imperative in L2 education: Vygotskian praxis and the research/practice divide.

Le, H., Janssen, J., \& Wubbels, T. (2018). Collaborative learning practices: teacher and student perceived obstacles to effective student collaboration. Cambridge Journal of Education, 48(1), 103-122. https://doi.org/10.1080/03 05764X.2016.1259389.

Lemghari, E. M. (2019). A metaphor-based account of semantic relations among proverbs. Cognitive Linguistic Studies, 6(1), 158-184. https://doi.org/10.1075/ cogls.00034.lem. 
Liang, X. (2004). Cooperative learning as a sociocultural practice. Canadian Modern Language Review/La Revue canadienne des langues vivantes, 60(5), 637-668.

Lodico, M. G., Spaulding, D. T., \& Voegtle, K. H. (2010). Methods in educational research : from theory to practice (2nd ed.). San Francisco, CA: JosseyBass.

Lustig, M. W., \& Koester, J. (2010). Intercultural competence : Interpersonal communication across cultures (6th ed.). Boston: Allyn \& Bacon.

Manakin, V. (2015). Proverb commonalities in different languages and its application to Asian Pacific communication. Journal of Asian Pacific Communication, 25(1), 97-116. https://doi.org/10.1075/japc.25.1.06man

Mezzich, J. E. (2011). Human altruism and cooperation: Needs and the promotion of well-being in modern life. In R. W. Sussman \& C. R. Cloninger (Eds.), Origins of Altruism and Cooperation (pp. 345-347). New York: Springer.

Mieder, W. (2007). Yankee wisdom: American proverbs and the worldview of New England. In P. Skandera (Ed.), Phraseology and culture in English (pp. 205-234). Berlin: Mouton de Gruyter.

Mieder, W., Kingsbury, S. A., \& Harder, K. B. (1992). A Dictionary of American Proverbs. New York: Oxford University Press.

Minkov, M. (2013). Cross-cultural analysis : The science and art of comparing the world's modern societies and their cultures. Thousand Oaks, Calif.: SAGE Publications.

Mulisa, F., \& Mekonnen, S. K. (2019). The double-edged prospects of peerto-peer cooperative learning in Ethiopian secondary schools. Small Group Research, 50(4), 493-506. https://doi.org/10.1177/1046496419853866.

Nguyen, P.-M., Elliott, J. G., Terlouw, C., \& Pilot, A. (2009). Neocolonialism in education: Cooperative learning in an Asian context. Comparative Education, 45(1), 109-130.

Nguyen, P.-M., Terlouw, C., \& Pilot, A. (2005). Cooperative learning vs Confucian heritage culture's collectivism: confrontation to reveal some cultural conflicts and mismatch. Asia Europe Journal, 3(3), 403-419. https:// doi.org/10.1007/s10308-005-0008-4.

Nguyen, P.-M., Terlouw, C., \& Pilot, A. (2012). Cooperative Learning in Vietnam and the West-East educational transfer. Asia Pacific Journal of Education, 32(2), 137-152. https://doi.org/10.1080/02188791.2012.685233.

Pang, K.-y. S. (2014). 'Overthrowing' yesterday's ICM: (Re)focusing of meaning in a Hong Kong Chinese (Cantonese) constructional idiom. In M. Yamaguchi, D. Tay \& B. Blount (Eds.), Approaches to language, culture, and cognition: The intersection of cognitive linguistics and linguistic anthropology (pp. 6895). London: Palgrave Macmillan UK. 
Pizarro, D. A. (2007). Reciprocal altruism. In R. F. Baumeister \& K. D. Vohs (Eds.), Encyclopedia of social psychology (Vol. 2, pp. 729-730). California: Sage.

Price, T. (2008). Consequentialism. In R. Hamowy (Ed.), The encyclopedia of libertarianism (pp. 91-93). USA: Sage.

Rachels, J. (2013). Ethical Egoism. In R. Shafer-Landau (Ed.), Ethical theory: An anthology (2n ${ }^{\text {nd }}$ ed., pp. 193-199). MA, USA: Wiley-Blackwell.

Reis, H. T. (2007). Altruism. In R. F. Baumeister \& K. D. Vohs (Eds.), Encyclopedia of social psychology (Vol. 1, pp. 29-30). California, USA: Sage.

Samovar, L. A., Porter, R. E., McDaniel, E. R., \& Roy, C. S. (2015). Intercultural communication : A reader ( $14^{\text {th }}$ ed.). MA, USA: Cengage Learning.

Schwartz, S. H. (2011). Studying values: Personal adventure, future directions. Journal of Cross-Cultural Psychology, 42(2), 307-319. https://doi. org/10.1177/0022022110396925.

Sharan, Y. (2010). Cooperative learning: A diversified pedagogy for diverse classrooms. Intercultural education, 21(3), 195-203.

Sharifian, F. (2011). Cultural conceptualisations and language: Theoretical framework and applications. Amsterdam: John Benjamins.

Sharifian, F. (2014). Advances in cultural linguistics. In M. Yamaguchi, D. Tay \& B. Blount (Eds.), Approaches to language, culture, and cognition: The intersection of cognitive linguistics and linguistic anthropology (pp. 99-123). London: Palgrave Macmillan.

Sharifian, F. (2017). Cultural Linguistics: Cultural conceptualisations and language. Amesterdam: John Benjamins Publishing Company.

Slembrouck, S. (2020). Discourse analysis. In K. Tusting (Ed.), The Routledge handbook of linguistic ethnography (pp. 28-39). New York: Routledge.

Speake, J. (2015). Oxford dictionary of proverbs (6th ed.). NY, USA: Oxford University Press.

Takano, M., Wada, K., \& Fukuda, I. (2016). Reciprocal altruism-based cooperation in a social network game. New Generation Computing, 34(3), 257-272. https://doi.org/10.1007/s00354-016-0304-0.

Takano, Y., \& Osaka, E. (2018). Comparing Japan and the United States on individualism/collectivism: A follow-up review. Asian Journal of Social Psychology, 21(4), 301-316. https://doi.org/10.1111/ajsp.12322.

Tamimy, M. (2019). The cultural attitudes towards cooperative learning: What proverbs can offer. Journal of Intercultural Communication Research, 48(4), 416-434. https://doi.org/10.1080/17475759.2019.1639536.

Thanh, P. T. H. (2014). Implementing cross-culture pedagogies : Cooperative learning at confucian heritage (Vol. 25). London: Springer. 
Turner, M. E., \& Pratkanis, A. R. (2010). Groupthink. In J. M. Levine \& M. A. Hogg (Eds.), Encyclopedia of Group Processes \& Intergroup Relations (pp. 390-392). Thousand Oaks, CA: Sage.

Tusting, K. (2020). General introduction. In K. Tusting (Ed.), The Routledge handbook of linguistic ethnography (pp. 1-9). New York: Routledge.

Utz, S. (2004). Self-Construal and Cooperation: Is the Interdependent Self More Cooperative Than the Independent Self? Self and Identity, 3(3), 177190. https://doi.org/10.1080/13576500444000001.

Van den Bossche, P., Gijselaers, W. H., Segers, M., \& Kirschner, P. A. (2006). Social and cognitive factors driving teamwork in collaborative learning environments team learning beliefs and behaviors. Small Group Research, 37(5), 490-521.

van Vugt, M. (2010). Commons dilemma. In J. M. Levine \& M. A. Hogg (Eds.), Encyclopedia of group processes and intergroup relations (pp. 125-127). Thousand Oaks, CA: Sage.

Weigel, R. H., Hessing, D. J., \& Elffers, H. (1999). Egoism: Concept, measurement and implications for deviance. Psychology, Crime \& Law, 5(4), 349-378. https://doi.org/10.1080/10683169908401777.

Wong, Y. J., Wang, S.-Y., \& Klann, E. M. (2018). The emperor with no clothes: A critique of collectivism and individualism. Archives of Scientific Psychology, 6(1), 251-260. https://doi.org/10.1037/arc0000059.

$\mathrm{Yu}$, N. (2015). Embodiment, culture, and language. In F. Sharifian (Ed.), The Routledge handbook of language and culture (pp. 227-239). NY, USA: Routledge.

Zhou, W., \& Shi, X. (2011). Special Review Article: Culture in groups and teams: A review of three decades of research. International Journal of Cross Cultural Management, 11(1), 5-34. https://doi.org/10.1177/1470595811398799. 


\section{Appendix A}

The Proverbs of Appropriate Currency

\begin{tabular}{|c|c|c|}
\hline Proverb & $\begin{array}{c}N \text { in } \\
\text { COCA }\end{array}$ & $\begin{array}{l}\text { Latest } \\
\text { Use }\end{array}$ \\
\hline EVERY man for himself. & 264 & 2019 \\
\hline The MORE the merrier. & 257 & 2019 \\
\hline There is SAFETY in numbers. & 179 & 2019 \\
\hline NO harm, no foul. & 157 & 2019 \\
\hline It takes TWO to tango. & 141 & 2019 \\
\hline You SCRATCH my back, I'll scratch yours. & 58 & 2019 \\
\hline There is HONOUR among thieves. & 54 & 2019 \\
\hline One hand washes the other (and both wash the face). & 45 & 2019 \\
\hline EAST is east, and west is west. & 19 & 2019 \\
\hline A HOUSE divided cannot stand. & 17 & 2019 \\
\hline TWO heads are better than one. & 60 & 2018 \\
\hline MANY hands make light work. & 17 & 2018 \\
\hline EVERY little helps. & 8 & 2018 \\
\hline UNITED we stand, divided we fall. & 170 & 2017 \\
\hline GOOD fences make good neighbors. & 48 & 2017 \\
\hline God helps those who help themselves. & 28 & 2017 \\
\hline BUSINESS is war. & 19 & 2017 \\
\hline POLITICS makes strange bedfellows. & 14 & 2017 \\
\hline What you HAVE, hold. & 6 & 2017 \\
\hline LOVE begets love. & 2 & 2017 \\
\hline A TROUBLE/Problem shared is a trouble halved. & 4 & 2016 \\
\hline DEVIL take the hindmost. & 22 & 2015 \\
\hline TOO many cooks spoil the broth. & 16 & 2015 \\
\hline BIG fish eat little fish. & 8 & 2015 \\
\hline You don't get SOMETHING for nothing. & 23 & 2014 \\
\hline Neither a BORROWER nor a lender be. & 18 & 2014 \\
\hline COMPARISONS are odious. & 8 & 2014 \\
\hline He TRAVELS fastest who travels alone. & 2 & 2014 \\
\hline JUDGE not, that ye be not judged. & 25 & 2012 \\
\hline It takes a whole VILLAGE to bring up a child. & 10 & 2012 \\
\hline UNION/Unity is strength. & 6 & 2012 \\
\hline One man's LOSS is another man's gain. & 3 & 2012 \\
\hline One HAND for yourself and one for the ship. & 3 & 2012 \\
\hline BETTER the devil you know than the devil you don't know. & 3 & 2012 \\
\hline The EYE of a master does more work than both his hands. & 3 & 2012 \\
\hline BETTER be envied than pitied. & 2 & 2012 \\
\hline He that GOES a-borrowing, goes a-sorrowing. & 2 & 2012 \\
\hline Every TUB must stand on its own bottom. & 2 & 2012 \\
\hline
\end{tabular}




\begin{tabular}{llc}
\hline \multicolumn{1}{c}{ Proverb } & N in & Latest \\
& COCA & Use \\
\hline He GIVES twice who gives quickly. & 2 & 2012 \\
Why KEEP a dog and bark yourself? & 3 & 2012 \\
$\begin{array}{l}\text { If every man would SWEEP his own doorstep the city would soon } \\
\text { be clean. }\end{array}$ & 1 & 2012
\end{tabular}

If you are not the LEAD dog, the view never changes.

32010

Note. Words in CAPITAL, are head words based on which Oxford Dictionary of Proverbs is sorted. 